\title{
МОНГОЛ ОРНЫ ХӨРС САЛХИАР ЭЛЭГДЭХ ҮЙЛ ЯВЦЫГ ҮНЭЛСЭН СУДАЛГААНЫ ҮР ДҮНГЭЭС
}

\author{
Н.Мандах \\ ШУА-ийн Геоэкологийн хүрээлэн \\ Цахим шуудан: maaggi@yahoo.com
}

\begin{abstract}
Phenomenae commonly occuring in arid regions are dust storms. Adaptation mechanism associated with this phenomenon appears in various forms within ecological environments of the world largest desert and semi-deserts. However, due to adverse anthropogenic impacts as well as natural external and internal forces, transportation and accumulation of soil particles by wind intensifies, which accelerates the soil erosion processes in arid territories.

An equation for wind erosion computation used for this assessment was based on the Universal Wind Erosion Equation developed in 1961 by the US Department of Agriculture. When the WEQ equation used for Mongolia, the factors of unsheltered distance or distance for undisturbed wind flowing were not taken into consideration assuming that there is no barrier to hinder the wind force in the given for study area. Meanwhile soil surface was considered as an influencing factor to wind flow and soil surface roughness and obstacles were calculated from the digital elevation data.

The results demonstrate that there is a high degree of wind erosion along the desert zone, Great Lakes Depression, Lakes Valley. Especially soil around the Baruun Khuurain Khotgor, Altai Ovor govi, Ulaan Nuur Lake, Mandal-Ovoo territories have highest degree of wind erosion. Mongolia's steppe, desert steppe zones, especially steppes of Dornod and areas of Zamyn Uud and Sainshand belong to lands with moderate degree of soil erodibility. Wind erosion changes can clearly be observed in southern part of Govi-Altai, Bayankhongor, Umnugovi aimags, particularly, in valleys and depressions of gobi areas like Sharga, Nomin, Ingen hoovor, Galba, Borzon.
\end{abstract}

ТүлхүҮр үг: гандуу нутаг, хөрс салхиар элэгдэх, гадаргын тэгш бус байдал, бартаа саад, доройтльн зэрэглэл, салхины элэгдлийн тэгшитгэл

\section{ОРШИЛ}

Гандуу нутагт түгээмэл тохиолдох үзэгдэл бол шороон шуурга юм. Дэлхийн томоохон цөл, заримдаг цөлүүдийн экологийн нөхцөл энэ үзэгдэлд зохицсон байдаг бөгөөд зохицох механизм нь янз бүрээр илрэлээ олсон байдаг. Юуны түрүүнд гандуу нутгийн ургамал, элс шороо хуримтлагдахад дасан зохицсон байх бөгөөд элсэн хуримтлалыг өөртөө барих экологийн механизмыг агуулсан байдаг. Үүнээс гадна цөл, заримдаг цөлүүдийн гадарга жижиг хэмхдэст чулуугаар хучигдсан нь хөрсний нимгэн үе давхаргыг салхины нөлөөнөөс хамгаалах үүрэгтэй байдаг. Гэсэн хэдий ч хүний зохисгүй нөлөө, байгалийн гадаад болон дотоод хүчний нөлөөгөөр хөрс шороо салхиар зөөгдөх, хуримтлагдах явц эрчимжиж салхин гаралт хөрсний элэгдлийн үйл явц гандуу нутагт идэвхжих нь элбэг байдаг.

Хүний нөлөөгөөр явагдах хөрсний доройтлын үнэлгээ (GLASOD - The Global 
Assessment of Human Induced Soil Degradation) хөтөлбөрөөс гаргасан дүнгээр Дэлхийн эх газрын экосистемийн 548 сая га талбай салхины элэгдэлд их, бага хэмжээгээр өртсөн байна (Oldeman L.R., 1992). Нийт салхиар элэгдсэн талбайн 95 хувь нь сул ба дунд зэргийн доройтлын зэрэглэлд үнэлэгдсэн байгаагаас харахад дэлхийн хэмжээнд ойролцоогоор 26 сая га талбай дахин сэргэхгүйгээр салхины элэгдлийн үйл явцад өртжээ (Хүснэгт 1.).

Хөрс салхиар элэгдсэн газрын талбай (Oldeman L.R., 1992)

\begin{tabular}{|c|c|c|c|c|c|c|c|}
\hline \multirow{2}{*}{ Тив } & \multicolumn{3}{|c|}{ Доройтлын зэрэглэл, сая га } & \multirow{2}{*}{$\begin{array}{l}\text { Нийт, } \\
\text { сая га }\end{array}$} & \multirow{2}{*}{$\begin{array}{c}\text { Хөрсний } \\
\text { доройтлын } \\
\text { эзлэх хувь, } \\
\text { \% }\end{array}$} & \multirow{2}{*}{$\begin{array}{c}\text { Гандуу } \\
\text { бүс } \\
\text { нутагт }\end{array}$} & \multirow{2}{*}{$\begin{array}{c}\text { Чийглэг } \\
\text { бүс } \\
\text { нутагт }\end{array}$} \\
\hline & Сул & Дунд & $\begin{array}{l}\text { Хүчтэй ба } \\
\text { нэн хүчтэй }\end{array}$ & & & & \\
\hline Африк & 88 & 89 & 9 & 186 & 38 & 186 & 1 \\
\hline Ази & 132 & 75 & 15 & 222 & 30 & 206 & 16 \\
\hline Өмнөд Америк & 26 & 16 & - & 42 & 17 & 28 & 14 \\
\hline Төв Америк & + & 4 & 1 & 5 & 7 & \multirow{2}{*}{38} & \multirow{2}{*}{1} \\
\hline Хойд Америк & 3 & 31 & 1 & 35 & 36 & & \\
\hline Европ & 3 & 38 & 1 & 42 & 19 & 39 & 3 \\
\hline $\begin{array}{c}\text { Номхон далайн } \\
\text { бүс нутаг }\end{array}$ & 16 & - & + & 16 & 16 & 16 & + \\
\hline Дэлхий & 269 & 254 & 26 & 548 & 28 & 513 & 36 \\
\hline
\end{tabular}

Дээрхи хүснэгтээс харахад хөрс салхиар элэгдэх үйл явц Ази тивийн хувьд хөрсний доройтлын бүлэг үйл явцын 30 хувийг эзэлж байгаа бөгөөд 222 сая га талбай их, бага хэмжээгээр салхины элэгдэлд өртсөн байна.

Салхиар хөрсний өнгөн хэсэг зөөгдөх үйл явц нь ихэнхи тохиолдолд ургамал нөмрөг сийрэгжсэний улмаас Үүсдэг. Ургамал нөмрөг сийрэгжих олон шалтгаан байдгаас хамгийн голлох шалтгаан нь ган гачиг, бэлчээрийн талхлагдал, барилгын ажил болон уул уурхайтай холбоотой үйл ажиллагаа юм. Хөрс салхиар элэгдэх үйл явц нь уур амьсгал, ургамалжилт, хөрсний физик шинж чанар зэрэг хүчин зүйлсээр тодорхойлогдоно. Салхины элэгдэл нь усны эвдрэлээс эсрэгээр том мөхлөгт хөрсийг илүҮ зөөгдөлд оруулдаг тул хуурай, гандуу бүс нутагт нэн түгээмэл байгалийн үзэгдэл юм.

$$
\text { Дэлхийн тив бүрт хөрс салхиар }
$$

элэгдэх явц аль нэг хэмжээнд илэрч байгаа ч хамрах талбайн хувьд Ази, Африк тивүүд, нэн ялангуяа Сахелийн бүс, Аравийн хойг, Дундад Ази, Төв Азийн бүс нутагт илүү эрсдэлтэй байна. Монгол орны хувьд говь, хээрийн бүсийн хэмжээнд салхины элэгдэл, эвдрэлийн асуудлыг хөндөх шаардлагатай байдаг. Дэлхийн элэгдэл, эвдрэлийн эрсдлийн зургаас үзээд Монгол орны хэмжээнд элэгдэл нэн хүчтэй илрэх эрсдэл өндөр байгаа юм. Энэ нь ургамал нөмрөгийн сийрэг байдал, хөрсний мөхлөгзүйн өвөрмөц шинж чанар зэргээр тодорхойлогдоно.

Иймээс хөрс салхиар элэгдэх үйл явц, түүний үр дагаврыг цөлжилт, газрын доройтлын үнэлгээний нэг гол хүчин зүйл хэмээн дүгнэж болно. Энэхүү ажлын хүрээнд хөрс салхиар элэгдэх үйл явцыг WEQ буюу Wind Erosion Equation загвар ашиглан боловсруулсан болно. 


\section{СУДЛАГДСАН БАЙДАЛ}

Хөрс салхиар элэгдэх үйл явцыг хээрийн болон лабораторийн судалгаагаар тодорхойлох ажлууд 1930-аад оноос эхэлсэн гэж үздэг бөгөөд энэ хугацаанд салхи хөрсний элэгдэлд нөлөөлөгч хүчин гэдэг талаас нь голчлон судалж байсан (Fryrear D.W., Sutherland P.L., Davis G., et al., 2001). Нэг дор бүх хүчин зүйлийн нөлөөллийг тодорхойлох боломжгүй тул олон туршилтаар хүчин зүйл тус бүрийг тодорхойлдог. Байгаль дээр эдгээр тусгайлан тодорхойлсон хүчин зүйлс нь харилцан хамааралтай, бие биедээ нөлөөлдөг тул эдгээрийн хам нөлөөг загварчлалын аргаар үнэлдэг. Хөрс салхиар элэгдэх үйл явцыг үнэлэх анхны загвар болох Хөрсний элэгдлийн цогц тэгшитгэл (Universal Wind Erosion Equation)-ийг АНУ-ын Хөдөө аж ахуйн агентлагаас 1961 онд боловсруулсан ба хожим үүнийг Вудрофф нар салхины элэгдлийн тэгшитгэл (WEQ) нэртэйгээр сайжруулсан байна (USDA - Agricultural Research Service, 1961; Woodruff N.P., Siddoway F.H., 1965). Салхины элэгдлийн тэгшитгэлийг цорын ганц эмпирик загвар хэлбэрээр 30 гаруй жил ашиглаж ирсэн бөгөөд 1998 онд “Салхины элэгдлийн сайжруулсан тэгшитгэл” хэмээх загвар бий болгосон байна (Fryrear D.W., Bilbro J.D. et al., 1998). Эдгээр загваруудыг анхлан тодорхой талбайд, тухайлбал, тариалангийн талбай дээр ашиглаж ирсэн тул 2000 оныг хүртэл бүс нутгийг хамарсан салхины элэгдлийг үнэлэх орон зайн загвар байхгүй

\section{АШИГЛАСАН МЭДЭЭ БА АРГАЗУЙ}

Бидний ашигласан салхины элэгдлийн тэгшитгэл (Woodruff N.P., Siddoway F.H. 1965) нь АНУ-ын Хөдөө аж ахуйн агентлагаас 1961 онд боловсруулсан “Хөрсний элэгдлийн цогц тэгшитгэл (Universal Wind Erosion Equation)"'-д түшиглэсэн бөгөөд дээрх эрдэмтэд анх нийтлүүлж олны хүртээл болгосон байна. байсан гэхэд хилсдэхгүй юм.

Анхны гэмээр орон зайн загварыг Австралид боловсруулсан бөгөөд “Салхины элэгдлийн үнэлгээний загвар (WEMA Wind erosion assessment model)" нэртэй энэхүу загвар нь уур амьсгалын хүчин зүйл болон дэвсгэр гадаргын байдлыг сансрын мэдээ ашиглан үнэлгээ хийхэд зориулагдсан байна. Гэхдээ энэ загварын сул тал нь дээр дурьдсан 2 эмпирик загварт зайлшгүй ордог хөрсний чийгшил болон гадаргын атриашил гэсэн хүчин зүйлсийг харгалзаагүйд оршино (Leys J., McTainsh G., Shao Y.,, 2001).

Харин Газарзүйн Мэдээллийн Систем (ГМС) болон хиймэл дагуулын мэдээгээр элэгдлийг бүс нутгийн хэмжээнд үнэлэх ажилд салхины элэгдлийн сайжруулсан тэгшитгэл (RWEQ)-ийг ашигласан нь сонирхол татдаг юм (Zobeck T., Parker N., Guoding K., Haskell S. 2000). Эдгээр эрдэмтэд энэхүү тэгшитгэл дэх сансрын мэдээгээр тодорхойлсон зарим оролтын мэдээ нь олон янз утгыг агуулах тул тэдгээр мэдээг орон зайн хувьд хялбаршуулах замаар эмпирик тэгшитгэлүүдийг бүс нутагт ашиглах боломжтой гэсэн дүгнэлтийг хийсэн байна. Иймээс салхины элэгдэл эвдрэлийн загваруудыг бүс нутгийн төвшинд ашиглахдаа энэ үйл явцыг бүрдүүлэгч аль хүчин зүйл нь сонгон авсан масштабд нөлөө ихтэй болохыг урьдчилан тооцож улмаар тэдгээрийг зураглах ажлыг хийх нь илүү тохиромжтой юм байна. $\mathrm{E}=\mathrm{f}(\mathrm{I} . \mathrm{K}, \mathrm{C}, \mathrm{L}, \mathrm{V})$
Энд, $\mathrm{E}-$ жилд элэгдх хөрсний
боломжит хэмжээ, I - хөрсний салхинд
өртөх байдал, K - гадаргын тэгш бус байдал,
бартаа саад, C - уур амьсгалын хүчин зүйл,
$\mathrm{L}$ - ил задгай гадаргын нийт урт буюу салхи
саадгүй нэвтрэх зай, V - ургамлын бүрхэц.
Мэдээ. Судалгаанд ашигласан аргазүй 
нь WEQ загварыг ГМС-ийн орчинд тооцсонд оршино. Загварын үндсэн оролт болсон хүчин зүйл тус бүрийг ГМС-ийн орчинд растер хэлбэрээр тооцож үүссэн давхарга бүрийг давхцуулах замаар хөрсний элэгдлийн хэмжээг тооцон зурагласан болно.

Монгол орны хэмжээнд WEQ загварыг бодуулахдаа ил задгай гадаргын нийт урт буюу салхи саадгүй нэвтрэх зай гэсэн хүчин зүйлийг тооцоогүй болно. Учир нь салхины хүчийг бууруулах ямар нэг хаалт, хамгаалалт судалж буй масштабын хэмжээнд байхгүй хэмээн тооцсон. Харин газрын гадаргыг салхины урсгалд нөлөөлөх хүчин зүйл мөн гэж тооцож гадаргын тэгш бус байдал, бартаа саадыг өндөршлийн зургаас тооцон гаргасан. Бусад хүчин зүйлсийг тооцохдоо дараах мэдээ материалыг ашигласан. Үүнд:

- Цаг уурын ажиглалтын станцууд дээр тооцсон сарын нийлбэр хур тунадас, температур, салхины хурдны мэдээ 2000-2010 оноор;

- Монгол орны хөрсний зураг (Монгол Улсын Үндэсний атлас, 2009);

- Дэлхийн хөрсний мэдээллийн сан (FAO/IIASA/ISRIC/ISS-CAS/JRC, 2008);

- MODIS хиймэл дагуулын мэдээгээр тооцсон ургамлын нормчилсон индексийн 16 хоногийн мэдээ (MOD13Q1) 2000-2010 оноор;

- Газрын гадаргын хэлбэрзүйн тоон загвар (SRTM)-ын 90 м-ийн ялгах чадвартай мэдээ

Салхины элэгдэлд үзүүлэх уур амьсгалын нөлөө. Салхины элэгдэлд үзүүлэх уур амьсгалын нөлөөг салхины хурд, газрын гадаргын чийгшил хоёроор тодорхойлдог (Lyles, L., 1983; Woodruff N. P., Dean V. Armbrust, 1968). Энэ ҮзҮҮлэлтийг дараах томъёо ашиглан тооцсон:

$$
C=\frac{386 \cdot u^{3}}{(P E)^{2}}
$$

Энд, C - уур амьсгалын хүчин зүйл, и салхины дундаж хурд, РЕ - Торнвайтийн хур тунадасны ашигт байдлын индекс. РЕ -г дараах томъёогоор тодорхойлно:

$$
P E=3.16 \cdot \sum\left(\frac{P_{i}}{T_{i}+22}\right)^{10 / 9}
$$

Энд, Рі - сарын дундаж хур тунадас, Ті сарын дундаж температур.

Хөрсний элэгдэх байдал. Энэ хүчин зүйлийг лабораторийн нөхцөлд хөрсний гадаргын нэгж талбайгаас авсан дээжинд агуулагдах 0.84 мм-ээс дээш диаметр бүхий ширхэгт биетийн эзлэх хувиар тодорхойлдог (Chepil, W.S., 1942). Монголын хувьд хөрсний мөхлөгийн талаархи мэдээлэл төдийлөн элбэг биш тул хөрсний физик шинжчанарыг Дэлхийнхөрсниймэдээллийн сан (FAO/IIASA/ISRIC/ISS-CAS/JRC, 2008) ашиглан тодорхойлж тэдгээрт агуулагдах мөхлөгзүйн мэдээлэлд тулгуурлан нийт 8 төрлийн хөрсний элэгдэх байдлын ангийг тогтоосон. Үүнээс гадна карбонатлаг хөрс элэгдэлд илүү өртөмтгий байдаг тул хөрсөн дахь карбонатын хэмжээ 5 хувиас илүү тохиолдолд салхинд их өртөмтгий гэж тооцсон (Хүснэгт 2).

ХУснэгт 2

Хөрсний элэгдэх байдал ба хөрсний механик бүрэлдэхүYн (Chepil, W.S., 1942)

\begin{tabular}{|c|c|c|}
\hline Давамгайлах мөхлөгийн хэмжээ & Карбонатлаг хөрс & Карбонатлаг биш хөрс \\
\hline Элс & 3 & 3 \\
\hline Элсэнцэр & 2,45 & - \\
\hline Элсэрхэг & 2,13 & 2,75 \\
\hline Шавранцар & 1,49 & 1,63 \\
\hline Хөнгөн шавранцар & 2,75 & - \\
\hline Дунд шавранцар & 2,13 & 2,75 \\
\hline Хүнд шавранцар & 1,63 & - \\
\hline
\end{tabular}


Гадаргын тэгш бус байдал, бартаа саад. Салхины элэгдлийн орон зайн хуваарилалтанд гадаргын байдал ихээхэн нөлөөтэй. WEQ загвар нь өмнө дурьдсанчлан загвар талбайн хэмжээнд зориулагдсан бөгөөд энэ тохиолдолд хөрсний гадаргын тэгш бус байдлыг тооцож гаргах шаардлагатай байдаг. Гадарга “барзгар" буюу бартаа их байх тусам салхины хүч саарч улмаар салхины хөрс элээх чадавхи буурна гэж ойлгож болно. Бүс нутгийн хэмжээнд энэ асуудлыг судлахдаа газар нутгийн физик гадаргын нөлөөг салхиар туугдах шороон урсгалд тооцох нь илүү тохиромжтой. Энэ үүднээс судалгаанд 90 м-ийн ялгах чадвартай гадаргын тоон загварыг ашигласан бөгөөд нэгж талбайд цэгүҮдийн харьцах өндөрүүдийн хоорондын хэлбэлзлийг суурь болгон авсан. Тооцоог хийхдээ нэгж талбайг хааш хааш 1 кмийн радиуст авч үзэж дараах дарааллаар гүйцэтгэсэн. Үүнд:

1. ЦэгүҮдийн харьцах өндрийг ArcGIS/Spatial Analyst программын тусламжтайгаap Focal Range функцийг ашиглан 1000 м-ийн радиуст тооцсон.

2. Саадын зэрэглэлийг гаргахдаа Зинг, Вудрофф (Zingg A.W., Woodruff N.P., 1951) нарын томъёог ашигласан.

$$
K=4 \cdot\left(1-\frac{H}{L}\right)
$$

Энд, Н - харьцах өндөр, м, L - талбайн урт, м.

ЦэгүҮдийн харьцах өндрийн хоорондын

\section{СУДАЛГААНЫ ҮР ДҮН}

Уур амьсгалын хүчин зүйл. Нийт 70 станцын хэмжээнд уур амьсгалын нөлөөг тооцож үзэхэд салхины элээх байдлын хамгийн бага утга Тосонцэнгэл станцид (0.1) тэмдэглэгдсэн бол хамгийн их хэмжээ Эхийн гол станцид (1611.0) байна. Салхины элээх байдлыг 2000, 2010 онуудаар авч хэлбэлзэл ихтэй газруудыг салхины элээх чадавхид сөрөг нөлөөтэй буюу ийм газарт салхины элэгдэл бага хэмээн тооцсон. Гадаргын тэгш бус байдал, бартаа саадын хүчин зүйлийн үзүүлэлт нь 0-1-ийн хооронд утга авах ба 1-д ойртох утгууд нь салхины элэгдэлд их нөлөөтэйг илтгэнэ.

Ургамал нөмрөгийн хүчин зүйл. Ургамал нөмрөгийн хүчин зүйл нь ил задгай талбайтай харьцуулахад аль нэг ургамал бүлгэмдэлтэй газар хөрсний зөөгдөл аль хир өөрчлөгдөж байгааг тодорхойлоход оршино (Wischmeier W.H., Smith D.D., 1978). Хөрс салхиар элэгдэх үйл явц усны эвдрэлээс ялгаатай нь гэвэл ургамлын өндөр салхины хурд, хүчинд илүү нөлөөтэй байдагт оршино. Иймээс энэхүү судалгаанд ургамал нөмрөгийн өндрийн үзүүлэлтийг тооцохдоо ургамлын нормчилсон индексээс илүү навчны талбайн индексийг тооцох нь зөв хэмээн үзсэн. Ингэхдээ навчны талбай их байх тусам ургамлын өндөр их байна гэсэн урьтал таамаг нөхцөл тавьсан болно (Rui Mao, Chang-Hoi Ho et al., 2013). Энэ судалгаанд MODIS FPAR/LAI бүтээгдэхүүнийг ашигласан бөгөөд говь, цөлийн бүсэд энэ мэдээ нь тодорхойлогддоггүй учир ургамлын нормчилсон индексээс хамаарсан шугаман тэгшитгэлийг ашигласан.

$$
L A I=2.745 \cdot \mathrm{NDVI}-0.201
$$

Энд, LAI - навчны талбайн индекс, NDVI -ургамлын нормчилсон индекс.

Үзэхэд нийт нутгаар дундажласан утга 3540 хооронд хэлбэлздэг байна. Салхи ихтэй гэгдэх Их нууруудын хотгор, Нууруудын хөндий, Борхойн тал зэрэг газруудаар уур амьсгалын хүчин зүйлийн тоон утга 30 -аaс дээш байна. 
Салхины элэгдлийн уур амьсгальн хүчин зүйлийг тооцсон байдал

ХУснэгт 3

\begin{tabular}{|c|c|c|c|c|c|}
\hline Д/Д & Станцын нэр & $\begin{array}{c}\text { PЕ утга } 2000 \\
\text { оноор }\end{array}$ & $\begin{array}{c}\text { PЕ утга } 2010 \\
\text { оноор }\end{array}$ & $\begin{array}{c}\text { С хүчин зүйл } \\
2000 \text { оноор }\end{array}$ & $\begin{array}{c}\text { С хүчин зүйл } \\
2010 \text { оноор }\end{array}$ \\
\hline 1 & Ренчинлхүмбэ & 28.84 & 26.81 & 0.5 & 0.4 \\
\hline 2 & Хатгал & 35.37 & 25.51 & 0.1 & 0.4 \\
\hline 3 & Улаангом & 8.83 & 8.27 & 1.4 & 0.9 \\
\hline 4 & Баруунтуруун & 14.64 & 20.54 & 0.7 & 0.2 \\
\hline 5 & Өлгий & 8.30 & 7.40 & 5.2 & 6.6 \\
\hline 6 & Өмнөговь & 11.93 & 12.17 & 2.7 & 1.0 \\
\hline 7 & Завхан & 3.92 & 4.89 & 14.8 & 9.9 \\
\hline 8 & Ялалт & 12.63 & 9.11 & 1.4 & 2.5 \\
\hline 9 & Ховд & 6.67 & 13.55 & 4.2 & 0.3 \\
\hline 10 & Дөрвөлжин & 7.91 & 8.75 & 3.9 & 2.4 \\
\hline 11 & Баян-Уул & 17.56 & 15.45 & 0.5 & 0.4 \\
\hline 12 & Цэцэн-Уул & 17.08 & 22.86 & 0.6 & 0.4 \\
\hline 13 & Тосонцэнгэл & 10.94 & 23.10 & 0.1 & 0.0 \\
\hline 14 & Тариат & 21.09 & 25.71 & 0.4 & 0.3 \\
\hline 15 & Тариалан & 16.39 & 22.40 & 0.5 & 0.3 \\
\hline 16 & Мөрөн & 17.81 & 18.56 & 0.6 & 0.2 \\
\hline 17 & Хутаг & 19.99 & 22.62 & 0.6 & 0.4 \\
\hline 18 & Эрдэнэт & 29.05 & 25.97 & 0.2 & 0.1 \\
\hline 19 & Эрдэнэмандал & 25.21 & 22.47 & 0.4 & 0.5 \\
\hline 20 & Булган & 24.02 & 26.10 & 0.3 & 0.1 \\
\hline 21 & Сүхбаатар & 33.19 & 15.22 & 0.1 & 0.5 \\
\hline 22 & Баруунхараа & 21.35 & 22.49 & 0.3 & 0.2 \\
\hline 23 & Opхон & 21.59 & 18.01 & 0.4 & 0.3 \\
\hline 24 & Ерөө & 25.52 & 16.39 & 0.2 & 0.3 \\
\hline 26 & Угтаал & 24.46 & 23.60 & 0.6 & 0.5 \\
\hline 27 & Дадал & 19.91 & 30.75 & 0.3 & 0.1 \\
\hline 28 & Дашбалбар & 17.79 & 27.95 & 1.6 & 0.6 \\
\hline 29 & Биндэр & 20.92 & 33.07 & 0.8 & 0.2 \\
\hline 30 & Чойбалсан & 9.61 & 19.10 & 3.3 & 0.6 \\
\hline 31 & Дөчинжил & 7.90 & 8.67 & 3.3 & 2.4 \\
\hline 32 & Зэрэг & 3.79 & 4.32 & 18.9 & 7.4 \\
\hline 33 & Байтаг & 1.93 & 3.83 & 76.2 & 11.1 \\
\hline 34 & Тонхил & 6.30 & 9.06 & 16.3 & 7.2 \\
\hline 35 & Улиастай & 14.08 & 18.86 & 0.5 & 0.2 \\
\hline 36 & Баянбулаг & 10.71 & 14.19 & 3.4 & 1.3 \\
\hline 37 & Алтай & 10.79 & 16.05 & 4.7 & 1.8 \\
\hline 38 & Цэцэрлэг & 22.06 & 27.48 & 0.4 & 0.2 \\
\hline 39 & Галуут & 9.72 & 21.24 & 1.3 & 0.2 \\
\hline 40 & Хужирт & 21.84 & 16.20 & 0.7 & 0.7 \\
\hline 41 & Эрдэнэсант & 17.72 & 23.65 & 1.2 & 0.5 \\
\hline 42 & Баянхонгор & 7.25 & 16.37 & 5.4 & 1.0 \\
\hline 43 & Арвайхээр & 12.08 & 15.46 & 2.7 & 1.4 \\
\hline 44 & Зуунмод & 14.23 & 19.06 & 1.6 & 0.4 \\
\hline 45 & Буянт-Ухаа & 16.27 & 16.21 & 0.9 & 0.7 \\
\hline 46 & Улаанбаатар & 26.08 & 16.84 & 0.2 & 0.3 \\
\hline
\end{tabular}




\begin{tabular}{|c|l|c|c|c|c|}
\hline 47 & Мааньт & 16.56 & 14.64 & 1.0 & 1.4 \\
\hline 48 & Чойр & 6.84 & 5.56 & 6.9 & 13.2 \\
\hline 49 & Баян-Овоо & 16.57 & 16.76 & 1.6 & 1.1 \\
\hline 50 & Өндөрхаан & 12.99 & 17.70 & 2.8 & 1.1 \\
\hline 51 & Баруун-Урт & 9.85 & 12.65 & 2.5 & 1.8 \\
\hline 52 & Халхгол & 16.25 & 17.05 & 1.8 & 1.6 \\
\hline 53 & Матад & 14.28 & 12.60 & 2.2 & 2.3 \\
\hline 54 & Эрдэнэцагаан & 16.71 & 9.85 & 1.8 & 6.7 \\
\hline 55 & Тоорой & 4.12 & 3.59 & 9.1 & 12.8 \\
\hline 56 & Жинст & 6.98 & 6.28 & 11.8 & 14.3 \\
\hline 57 & Сайхан-Овоо & 5.79 & 3.38 & 7.0 & 29.7 \\
\hline 58 & Богд & 8.51 & 13.86 & 6.3 & 2.3 \\
\hline 59 & Сайхан & 8.93 & 9.98 & 14.5 & 11.5 \\
\hline 60 & Мандалговь & 8.61 & 6.02 & 7.4 & 18.5 \\
\hline 61 & Цогт-Овоо & 3.26 & 6.81 & 39.6 & 10.2 \\
\hline 62 & Мандах & 4.58 & 7.23 & 44.4 & 15.5 \\
\hline 63 & Баяндэлгэр & 14.23 & 11.31 & 3.1 & 4.0 \\
\hline 64 & Сайншанд & 11.14 & 6.44 & 4.4 & 13.7 \\
\hline 65 & Замын-Үүд & 8.82 & 9.05 & 5.3 & 4.0 \\
\hline 66 & Эхийнгол & 3.32 & 3.08 & 45.3 & 38.7 \\
\hline 67 & Даланзадгад & 6.99 & 12.46 & 6.3 & 1.7 \\
\hline 68 & Гурвантэс & 3.96 & 4.66 & 32.0 & 23.9 \\
\hline 69 & Ханбогд & 6.18 & 12.23 & 17.1 & 3.9 \\
\hline 70 & Хөвсгөл & 6.18 & 7.69 & 9.9 & 7.2 \\
\hline
\end{tabular}

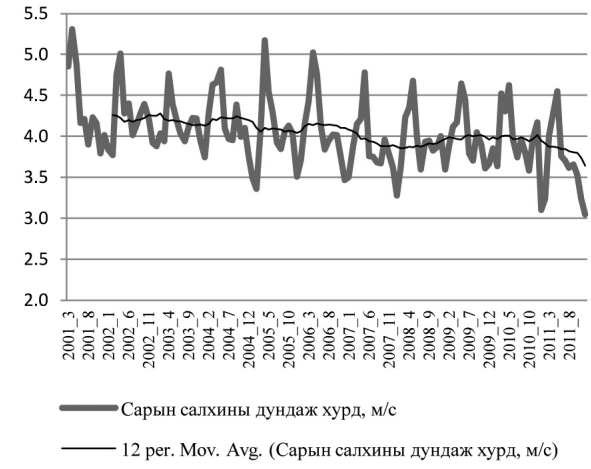

Зураг 1. Салхины сарын дундаж хурдны өөрчлөлт

Уур амьсгалын хүчин зүйлийн нэг гол бүрэлдэхүүн хэсэг бол салхины хурд юм. Монгол орны хэмжээнд 2000-2010 оны хооронд салхины дундаж хурд (нийт нутгаар дундажласан байдлаар) 0.05 м/сээр буурсан байна. Гэхдээ хөрс элээх чадавхитай 5 м/с ба түүнээс дээш хурдтай салхины тохиолдол нэмэгдэх хандлагатай

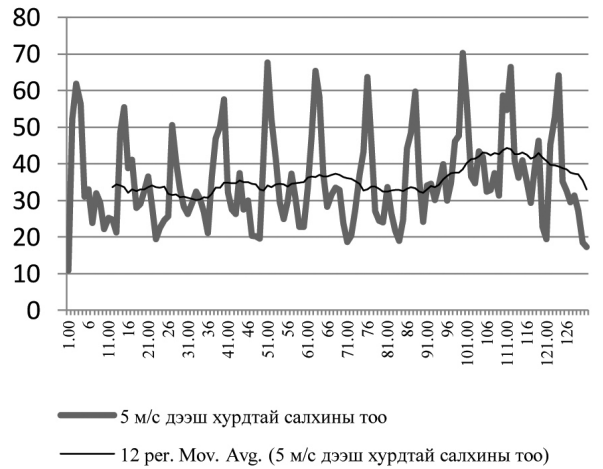

Зураг 2. 5 м/с-ээс дээм хурдтай салхины тохиолдол

байна.

Хөрсний элэгдэх байдал. Хөрсний элэгдэх байдлыг хөрсний хэвшинж бүр дээр тодорхойлсон бөгөөд ингэхдээ хөрсний физик шинж чанарын үзүүлэлтүүдийг “Дэлхийн хөрсний мэдээллийн сан “ (FAO/ IIASA/ISRIC/ISS-CAS/JRC, 2008) ашиглан тооцсон болно. 
Хөрсний элэгдэх байдал (К) хүчин зүйлийн эзлэх талбай, чанарын Үнэлгээ

\begin{tabular}{|c|c|c|c|}
\hline Д/д & Хөрсний элэгдэх байдал & Эзлэх талбай & Чанарын үнэлгээ \\
\hline 1 & 1,49 & 32.4 & бага \\
\hline 2 & 1.63 & 2.2 & \multirow{2}{*}{ дунд } \\
\hline 3 & 1,98 & 3.5 & \\
\hline 4 & 2,13 & 15.9 & \multirow{3}{*}{ их } \\
\hline 5 & 2,45 & 19.6 & \\
\hline 6 & 2,75 & 20 & \\
\hline 7 & 3 & 4.5 & Маш их \\
\hline
\end{tabular}

Монгол орны нийт хөрсний 30 гаруй хувь нь элэгдэлд их болон нэн их өртөмтгий гэж ангилагдаж байна. Харин бага зэрэг элэгдэлд өртөмтгий хөрс маш бага талбайг эзэлж дунд зэрэг өртөмтгий хөрс 30 гаруй хувьд тархсан байна.

Нутаг дэвсгэрийн хуваарилалтын хувьд хөрсний элэгдлийн зэрэглэл харьцангуй их утгатай буюу тогтвортойд тооцогдох хөрс уулын хээр, жинхэнэ хээр, хуурай хээрийн өмнөд хэсгүүд болон шал, шалархаг хөрс тархсан цөл газруудаар тархсан байна. Салхины элэгдлийн үйл явцад өртөмтгий хэлбэрийн хөрсөнд элсэн хуримтлалууд, хээрийн, хуурай хээрийн, цөлөрхөг хээрийн болон цөлийн бүсийн хөрсний хэв шинжүүд хамрагдана.

Гадаргын тэгш бус байдал, бартаа саад. Монгол орны хэмжээнд салхины урсгалын чиглэлийг үлэмж (макро), бэсрэг (мезо), бичил (микро) төвшнүүдэд ангилан ойлгох нь зүйтэй юм. Нутаг дэвсгэрийн хэмжээнд агаарын орчил урсгал, түүнийг дагаад салхины чиглэл хүчний хуваарилалтанд гадаргын тэгш бус байдал ихээхэн нөлөөтэй. Ийнхүү Монголын өмнөд хагас, Их Нууруудын хотгор, Нууруудын хөндий, Дорнод Монголын өмнөд хэсгээр салхины хурд, хүч илүү ихтэй байдаг бол уулархаг бүс нутгуудад гадаргын нөмөрлөх нөлөөгөөр салхины хурд, хүч харьцангуй бага байдаг. Бэсрэг төвшинд салхины горимыг авч үзвэл томоохон уулсын дотоод болон уул хоорондын хөндий, хотгоруудаар салхины хүч нэмэгддэг нь уулсын өндрөөс хамааран салхины урсгалыг хаах чадвар тодорхой зайнаас буурдагтай холбоотой.
Уул, толгод зэрэг гадаргын эерэг хэлбэрүүдийн хувьд орон нутгийн салхины хурд, чиглэл, хүчний нөлөө нь салхин талын энгэр болон хотгоруудаа дагаж нэмэгдэнэ.

Салхины элэгдэлд үзүүлэх гадаргын хүчин зүйлийн орон зайн хуваарилалтаас авч Үзэхэд нийт нутгийн 19.8 хувь нь нээлттэй ил задгай талбай байгаа бол 39.0 хувьд нь салхинд үзүүлэх гадаргын нөлөө бараг үгүй хэмээн тооцож болохоор байна.

Ургамал нөмрөгийн хүчин зүйл. Салхины хөрсөнд үзүүлэх нөлөөг тооцохдоо хөрсний ширхэг гадаргаар өнхрөх (creep), үсчин хийсэх (saltation) болон дэгдэн туугдах (suspension) гэсэн гурван төлөв байдлаар зөөгдөх нийт хэмжээгээр нь тооцдог. Өмнөх судалгааны дүнгүүдээс Үзэхэд (Fryrear D.W., Bilbro J.D. et al., 1998; USDA - Agricultural Research Service, 1961; Woodruff N.P., Siddoway F.H., 1965) элэгдэж буй хөрсний 60-70 хувь нь өнхрөх, үсчих хэлбэрээр зөөгддөг ба үүнээс хамгаалах гол зүйл нь ургамлан нөмрөг байдаг. Иймээс салхины элэгдэл эвдрэлийн хувьд навчны индексийн үзүүлэлтийг сонгон авсан болно.

Навчны индексийн орон зайн хуваарилалт ерөнхийдөө ургамлын нормчилсон индексийн хуваарилалттай дүйдэг боловч дан ой эзэлсэн талбайгаас бусад газарт харьцангуй бага утгыг агуулж байгаa юм. Иймд ургамал нөмрөгийн салхины элэгдэлд үзүүлэх нөлөө тус орны хэмжээнд харьцангуй бага буюу ой хөвчөөс бусад бүс нутагт намхан, навчны талбай багатай ургамал зонхилж байна. 


\section{ДҮГНЭЛТ}

Дээрх хүчин зүйлүүдийг ашиглан тооцсон хөрсний элэгдлийн 2000, 2010 оны зургуудаас харахад говийн бүс нутаг, Их нууруудын хотгор, Нууруудын хөндий дагуу элэгдлийн зэрэглэл өндөр гарсан байна. Ялангуяа Баруун хуурайн хотгор, Алтайн өвөр говь, Улаан нуур, Мандал-Овоо орчим хамгийн өндөр зэрэглэлтэй байна. Эдгээр нутгуудад ургамал нөмрөг тачир сийрэг байхаас гадна гадаргын налуу, бартаа саад багатай байгаа нь нөлөөлсөн хэрэг. Өөрөөр хэлбэл бидний тооцсон үзүүлэлт бүр эдгээр газруудад өндөр утгатай гарч байна.

Дунд зэргийн зэрэглэлд манай улсын хээр, цөлийн хээрийн бүс нутаг, ялангуяа дорнодын тал, дорнод говийн Замын Үүд, Сайншанд орчмын газар нутгууд хамрагдана. Хөрсний элэгдэлд өртөөгүй буюу сайжирсан газарт уулархаг нутаг бүхэлдээ багтана.

Хөрс салхиар элэгдэх үйл явцын өөрчлөлт Говь-Алтай, Баянхонгор, Өмнөговь аймгуудын өмнөд талын буюу Шарга, Номин, Ингэн хөөвөр, Галба, Борзонгийн говиудын хотос хоолой дагуу тод ажиглагдах ба 2000, 2010 онуудыг харьцуулсан байдлаар авч үзвэл эдгээр газруудаас жилд 165.7 тн/га хөрс зөөгдөж байгаа тооцоо гарсан болно. Харин Их нууруудын хотгорын баруун хэсэг буюу Хар ус нуур, Буянт голын сав дагуу нутагт хөрс салхиар элэгдэх үйл явц жилд 57.7 тн/ га-гаар буурсан үзүүлэлттэй байна.

\section{Аиигласан бүтээлийн жагсаалт}

Chepil, W.S. (1942). Measurement of wind erosiveness of soils by the dry sieving procedure. Scientific Agriculture, 25 , 154-160.

FAO/IIASA/ISRIC/ISS-CAS/JRC. (2008). Harmonized World Soil Database (version 1.0). Rome: FAO.

Fryrear D.W., Bilbro J.D. et al. (1998). Revised wind erosion equation. Technical bulletin No.1: USDA-ARS, Southern plain area cropping systems research laboratory.

Fryrear D.W., Sutherland P.L., Davis G., et al. (2001). Wind erosion estimates with RWEQ and WEQ. In M. R. Stott D.E., Sustaining the Global Farm. Selected papers from the 10th International Soil Coservation Organization Meeting (pp. 760-765). Purdue University and USDA-ARS National Soil Erosion Research Laboratory.

Laflen et al. (1991). WEPP soil erodibility experiments for rangeland and cropland soils. J. Soil and Water Conservation, 46(1):39-44.

Lal R. (1990). Soil erosion in the tropics: principles and management. New York: McGraw-Hill. Leys J., McTainsh G., Shao Y.,. (2001). Wind erosion monitoring and modeling techniques in Australia. . Sustaining the Global Farm, Selected Papers from the 10th International Soil Conservation Organization Meeting May 24-29, 1999 (pp. 940-950). Richmond: Purdue University.

Lyles, L. (1983). Erosive wind energy distributions and climatic factors for the West. Journal of Soil and Water Conservation, 38(2): , 106-109.

Morgan R.P.C., Quinton J.N., Smith R.E. et al. . (1998). The European Soil Erosion Model (EUROSEM): a dynamic approach for predicting sediment transport from fields and small 
catchments. Earth Surface Processes and Landforms , 23(6)527-544.

Oldeman L.R. (1992). Global extent of soil degradation. ISRIC Bi-annual report.

Renard K.G., Freimund J.R. (1994). Using monthly precipitation data to estimate the R factor in the revised USLE. Journal of Hydrology 157, 287-306.

Römkens M.J. (1985). The soil erodibility factor. In S. W. El-Swaify, Soil erosion and conservation. Ankeny: Soil Conservation Society of America.

Römkens M.J.M, Prasad S.N., Poesen J.W.A. (1986). Soil erodibility and properties. . 13th congress of the Int. Soc. Of Soil Sci., (pp. 492-504). Hamburg, Germany 5,

Rui Mao, Chang-Hoi Ho et al. (2013). The influence of vegetation variation on Northeast Asian dust activity. Asia-Pacific J. Atmof. Sci., 49(1), 87-94.

USDA - Agricultural Research Service. (1961). A universal equation for measuring wind erosion. USDA-ARS. 22-69, 1-22.

Wischmeier W.H., Smith D.D. (1978). Predicting rainfall erosion losses - a guide for conservation planning. Agriculture Handbook 537: U.S. Department of Agriculture.

Woodruff N. P., Dean V. Armbrust. (1968). A monthly climatic factor for the wind erosion equation. Journal of Soil and Water Conservation, 23:3 .

Woodruff N.P., Siddoway F.H. (1965). A wind erosion equation. Soil Sci.Soc.Am.Proc , 29:602608.

Zingg A.W., Woodruff N.P. (1951). Calibration of a portable tunnel for simple determination of roughness and drag on field surfaces. Agron. J. 43(4): , 191-193.

Zobeck T., Parker N., Guoding K., Haskell S. (2000). Scaling-up from field to region for wind erosion prediction on cropland using GIS. Agriculture, ecosystems and environment .

Монгол Улсын Үндэсний атлас. (2009). Улаанбаатар: Доржготов Д. (ред.). 